\title{
The repeated extracorporeal shock waves and the renal parenchyma injury on normal and diabetic rats ${ }^{1}$
}

\author{
A repetição de ondas de choque extracorpóreas e a lesão do parênquima renal \\ em ratos normais e diabéticos
}

\author{
Vicente Massaji Kira ${ }^{2}$, Djalma José Fagundes ${ }^{3}$, César Orlando Peralta Bandeira ${ }^{4}$, Anna Tereza Negrini Fagundes 5 , \\ Valdemar Ortiz \\ 1. Work performed at Surgery and Experimentation Post-Graduate Program, Federal University of São Paulo (UNIFESP), Brazil. \\ 2. Master, Assistant Professor of Urology, State University of Maringá (UEM), Paraná, Brazil. \\ 3. PhD, Associate Professor, Surgery Division Operative Technique and Experimental Surgery, Department of Surgery, UNIFESP, Brazil. \\ 4. PhD, Associate Professor, Toracic Surgery, UEM, Paraná, Brazil. \\ 5. Graduate Student, School of Medicine, Santo Amaro University (UNISA), São Paulo, Brazil. \\ 6. Full Professor, Urology Division, Department of Surgery, UNIFESP, Brazil.
}

\begin{abstract}
Purpose: To assess the effect of repeated extracorporeal shock waves (ESW) on renal parenchyma of normal and diabetic rats. Methods: 40 normal rats (A) and 40 diabetic rats (B) were assigned for ESW (Direx Tripter X1 ${ }^{\circledR}-14$ KVA) as follow: A1/B1 and A3/B3 no ESW; A2/B2 one ESW (2,000 SW); A4/B4 two ESW (4,000 SW) in an elapsed 14 days. All the animals were sacrificed 3 days after the ESW and samples of renal parenchyma were histological prepared, stained by H\&E. For each animal the frequency of hemorrhage focus (HF) in the subcapasular, interstitial and glomerulus area was calculated (porcentage) on 20 randomly histological sections. Results: No one HF was identified in all normal or diabetic animals without ESW (A1, A3 and B1, B3). In the normal rats the HF frequency was similar to one ESW (subcapsular =15\%; interstitial $=20 \%$ and glomerular $=10 \%$ ) or repetead ESW (subcapsular $=25 \%$; interstitial =20\%; glomerular=10\%). In diabetic rats the occurence of HF with repetead ESW was more frequent (subcapsular $=40 \%$; interstitial $=30 \%$ and glomerular $=10 \%$ ) than with a single ESW (subcapsular $=25 \%$; interstitial $=15 \%$ and glomerular $=15 \%$ ). Conclusion: A single ESW or a repeated ESW caused a mild and similar damage on renal cortex of normal rats. In diabetic rats the repetead ESW may result in an accumulated damage, especially with focus of hemorrhage in subcapsular and interstitial tissue and glomerulus edema.
\end{abstract}

Key words: Kidney. Lithotripsy. High-Energy Shock Waves. Diabetes Mellitus. Rats.

\section{RESUMO}

Objetivo: Avaliar o efeito de repetidas ondas de choque extracorpóreas (OCE) sobre o parênquima renal de ratos normais e diabéticos. Métodos: 40 ratos normais e 40 ratos diabéticos foram distribuídos para aplicação de OCE (Direx Tripter X1 ${ }^{\circledR}$ - 14 KVA) como segue: A1/B1 e A3/B3 sem OCE; A2/B2 uma sessão de OCE (2000 OC); A4/B4 duas sessões de OC (4000 OC) num intervalo de 14 dias. Todos os animais foram sacrificados no $3^{\circ}$. dia após a aplicação da OCE e amostras de parênquima renal foram histologicamente preparados e corados em H\&E. Para cada animal foi calculado, em 20 campos aleatórios, a freqüência (em porcentagem) de focos hemorrágicos (FH) nas áreas subcapsular, intersticial e glomerular. Resultados: Nenhum foco hemorrágico foi identificado nos animais normais ou diabéticos que não receberam nenhuma OCE (A1, A3 e B1, B3). Nos ratos normais a freqüência de FH foi similar com uma sessão de OCE (subcapsular $=15 \%$; intersticial $=20 \%$ e glomerular $=10 \%$ ) ou duas sessões de OCE (subcapsular $=25 \%$; intersticial =20\%; glomerular $=10 \%$ ). Nos ratos diabéticos a ocorrência de FH com duas sessões de OCE foi mais freqüente (subcapsular =40\%; intersticial $=30 \%$ e glomerular $=10 \%$ ) do que com uma simples sessão de OCE (subcapsular $=25 \%$; intersticial $=15 \%$ e glomerular $=15 \%$ ). Conclusão: Uma única ou duas sessões de OCE causa um discreto e semelhante dano no parênquima renal de ratos normais. Nos ratos diabéticos a repetição da OCE pode resultar em acúmulo de danos, especialmente com FH nas áreas subcapsular e intersticial e no edema do glomérulo.

Descritores: Rim. Litotripsia. Ondas de Choque de Alta Energia. Diabetes Mellitus. Ratos. 


\section{Introduction}

The formation of stones in the urinary tract stems from a wide range of underlying disorders. There are many advances in genetics, pathophysiology, diagnostic imaging, medical treatment, medical prevention, and surgical intervention of nephrolithiasis. Despite of the advances on medical treatment and in surgical management of nephrolithiasis over the past decade, particularly in endoscope technology and techniques, the shock-wave lithotripsy remains the only non-invasive treatment method for stones ${ }^{1}$. Due to its efficacy and safety, the extracorporeal shock wave lithotripsy (ESWL) became the current procedure for treating renal stone either as monotherapy or combined with other forms of lithotripsy ${ }^{2}$. Shockwave lithotripsy predictably damages renal tissue and transiently reduces function in both kidneys ${ }^{3}$. The effects of shock waves on the renal parenchyma were studied through imaging scans, histopathological tests and plasmatic or urinary functional markers. The morphological and functional changes were transients and recovered in few days in dependence of characteristic of the equipment and the quantity of energy focused on stone and adjacent renal parenchyma ${ }^{4}$. The severity of the renal injury caused by ESWL is related to the number of shock waves administered $^{3}$. Considering the prompt recovery from the initial renal injury, a new lithotripsy session could be performed within a short time period. There is no guideline for time interval reapplication of ESWL, although experimental essay in dogs reported that shock wave reapplication with a 24-hour interval did not cause any increase in urinary n-acetyl-beta-glucosaminidase ${ }^{2}$ and another one related that shock wave reapplication, in rats, after 14 days does not increase the alterations in renal morphology caused by the first application ${ }^{5}$. On the other hand, the incidence of diabetes is increasing in industrialized and developing countries. The prevalence of renal stones in the diabetic population was recently estimated to be $21 \%$, i.e. more than twice the prevalence of stones in the general population ${ }^{6}$. The association of diabetic nephropathy and urolithiasis has a potential risk of structural or functional renal impairment and how much that risk may be improved by ESW is unknown ${ }^{7}$. The large use of ESWL currently, the poor knowledge about injury caused by re-treatment within a short time interval and the empirical way by which treatment is performed, stimulated the development of the present experimental model. Is there an association with extracorporeal shock waves (ESW) and renal parenchyma injury in diabetic animal? The objective of this work was to assess the effect of repeated ESW on renal parenchyma of normal and diabetic rats.

\section{Methods}

The experimental protocol was approved by the Ethics Committee of the Federal University of São Paulo - Escola Paulista de Medicina (UNIFESP - EPM), ratified and developed at Maringá State University (UEM). All the procedures followed, rigorously, the existent regulations about animal experimentation. A hundred male Wistar rats weighing between 250-300g were acclimated to laboratory conditions for 7 days and fed a standard rat chow and water ad libitum. All the surgical procedures and extracorporeal shock waves (ESW) were done under general anesthesia, using ketamine (60mg. $\mathrm{Kg}^{-1}$ ) and xylazine (5mg. $\left.\mathrm{Kg}^{-1}\right)$. At first, all animals were submitted to laparotomy and a radiopaque device (piece of radiopaque surgical gauze) with $0.2 \mathrm{~cm}$ of diameter was sutured at the adipose tissue near to the right renal pelvis. The standard position of the X-Ray-marker was confirmed by simple post-anterior radiographic method. After fourteen days of surgical procedure, in order to induce diabetes after overnight fasting, 50 rats (Group A) received a single intravenous dose of saline $\left(1.0 \mathrm{ml} . \mathrm{Kg}^{-1}\right)$. Other 50 rats (Group B) received a single intravenous dose (45 mg. $\mathrm{Kg}^{-1}$ ) of alloxan $^{8}$. Immediately after the injection of alloxan or saline solution all animals were maintained with free access to food. At sixth and third-sixth days after the injection of alloxan or saline solution, always at 4pm, the glycemia value was performed in all animals of both groups. From the hundred animals were selected 40 with normal glycemia for the group A (normal rats) and 40 with persistent glycemia over than $200 \mathrm{mg} / \mathrm{dl}$ for the group B (diabetic rats). Before the first ESW application the urine of 24 hours was collected for microalbuminuria value $(\mathrm{mg} / \mathrm{L})$ determination. For ESW treatment the animals were assigned to one of four groups. The animals of group A1 $(n=10)$ and B1 $(n=10)$ did not receive ESW and were sacrificed at $3^{\text {rd }}$ day; the groups A2 $(n=10)$ and $\mathrm{B} 2(\mathrm{n}=10)$ received $2,000 \mathrm{ESW}$ at $1^{\text {st }}$ day and another 2,000 ESW at $14^{\text {th }}$ day and were sacrificed at $17^{\text {th }}$ day; the groups A3 $(n=10)$ and B3 $(n=10)$ did not receive ESW and were sacrificed at $17^{\text {th }}$ day; the group A4 $(n=10)$ and $\mathrm{B} 4(\mathrm{n}=10)$ received $2,000 \mathrm{ESW}$ at the $1^{\text {st }}$ day and were sacrificed at $3^{\text {rd }}$ day. A Direx Tripter $X 1^{\circledR}$ lithotriptor $^{9}$ with 14 KVA of intensity, produced a tension ranging from 500 to 520 Bar and the focus system to be used was obtained by means of acoustic lens and the contact with the animal skin through a bag containing water and gel. Previously to the adjustment of focus system the radiopaque device was localized by fluoroscope monitor. The ESW were focused about $0.5 \mathrm{~cm}$ laterally to the radiopaque device and were applied 2,000 shock waves in each session. According to each group, 72 hours after the ESW, under anesthesia, the animal was submitted to a right nefrectomy and 3 fragments were collected from the area near the radiopaque device $(0.5 \mathrm{~cm})$ where was 
focused the ESW. The samples of renal parenchyma were fixed in $10 \%$ formalin solution, embedded in paraffin wax and $5 \mu \mathrm{m}$ sections were cut and stained with hematoxilin and eosin (H\&E). Histological evaluation was undertaken by an independent pathologist who had no knowledge of the experimental groups from which the specimens were derived. The evaluated parameters were hemorrhagic focus (HF) in the renal cortex (subcapsular, interstitial and glomerular areas). The macroscopic assessment was performed using the following grading scoring: 0 (no changes), 1 (mild $=1$ to $7 \mathrm{HF}$ ), 2 (moderate $=8$ to $15 \mathrm{HF}$ ) and 3 (severe $=15$ to $20 \mathrm{HF}$ ). The abnormalities detected in 20 random sites in every animal plate were subjectively scored and compared with the controls. The rate of occurence of HF (percentage) was calculated in three plates for each animal. In other 20 random places was measure the thicknesses $(\mu \mathrm{m})$ of the glomerulus and Bowman capsule, and then calculated the ratio glomerulus/ capsule. The statistical analysis was performed using the Mann-Whitney test due to the paired structure of data in order to compare the variation: A1xA2; A3xA4; B3xB4. The Exact Fisher test was performed due to the paired structure of data in order to compare the variation: A1xA2; A3xA4; B1xB2; A2xB2; A4xB4. The significance level was established at 0.05 or $5 \%$.

\section{Results}

The alloxan was effective to induce the diabetes and all animals from group B (diabetic) developed a functional impairment in microalbuminuria due to a mild diabetic nephropathy. There was a significant increase in microalbuminuria excretion $(\mathrm{p}<0.05)$ in all subgroups $\mathrm{B}$ (B1 to $\mathrm{B} 4$ ) in comparison with the non diabetic control group A (A1 to A4) as shown in Tables 1 and 2. Different superscript letters indicate statistically significant differences with regard to the corresponding control value (Figures 1 and 2). The analysis of 20 areas in the three plates stained by $H \& E$ as shown in characteristic photomicrography of Figure 1, allowed to perform the semi-quantitative evaluation and calculated the HF frequency (in percentage) that were plotted at Figure 3 (A, B and C). The frequency of absent subcapsular hemorrhage was quite similar in the normal rats with a single $(\mathrm{A} 4=85 \%)$ or repeated ESW (A2 = $75 \%$ ). However, in the diabetic rats the HF (mild and severe) were more frequent mainly after repeated ESW $(\mathrm{B} 2=40 \%)$ in comparison with repeated ESW (A2 = 25\%) in normal rats (Figure 3A). The mild and severe interstitial hemorrhage were low frequent in the normal rats, with one (A4 $=20 \%$ ) or two ESW (A2 = 20\%), that means $80 \%$ of $\mathrm{HF}$ absence in each group. In the diabetic rats the frequency of interstitial hemorrhage was more frequent with repeated ESW (B2 $=30 \%$ ) than one ESW (B4 $=15 \%)$ (Figure 3B). The frequency of glomerular hemorrhage was the same in normal rats with one ESW $(\mathrm{A} 4=10 \%)$ or repeated ESW (A2 $=10 \%)$. In the diabetic rats the frequency of HF was similar with one ESW (B4 $=10 \%)$ or repeated $\operatorname{ESW}(\mathrm{B} 2=15 \%)$ (Figure $3 \mathrm{C})$. Different superscript letters indicate statistically significant differences with regard to the corresponding group value.

TABLE 1 - Distribution of the microalbuminuria values $(\mu \mathrm{g} / \mathrm{L})$ in 24 hours urine, just before the first ESW. Values are given as mean \pm sd and median

\begin{tabular}{|c|c|c|c|c|c|c|c|c|}
\hline & \multicolumn{4}{|c|}{ Group A ( non Diabetes ) } & \multicolumn{4}{|c|}{ Group B (Diabetes ) } \\
\hline & A1 & A2 & A3 & A4 & B1 & B2 & B3 & B4 \\
\hline Mean & $6.3 a$ & $8.2 b$ & $5.9 \mathrm{c}$ & $6.0 \mathrm{~d}$ & $30.3 a$ & $30.3 b$ & $30.8 c$ & $31.7 \mathrm{~d}$ \\
\hline sd & 0.3 & 0.2 & 0.2 & 0.3 & 0.4 & 0.4 & 0.3 & 0.3 \\
\hline Median & 5.6 & 7.7 & 5.6 & 5.6 & 25.0 & 25.0 & 25.0 & 25.0 \\
\hline
\end{tabular}

Mann-Whitney test $(\mathrm{Z}$ crit $=2.12)$ : aA1 $<$ B1 $(\mathrm{Z}$ cal =3.74*); bA2 < B2 $(\mathrm{Z}$ cal =3.66*); cA3 $<$ B3 $(\mathrm{Z}$ cal =3.87* $)$ dA4 $<$ B4 $(\mathrm{Z}$ cal =3.84*)

TABLE 2 - Distribution of means (sd) and median of the ratio of measures of Bowman capsule and glomerulus diameters $(\mu \mathrm{m})$ in the groups of diabetics and non diabetics rats with one or two ESW

\begin{tabular}{|c|c|c|c|c|c|c|c|c|}
\hline & \multicolumn{4}{|c|}{ Group A (non Diabetes ) } & \multicolumn{4}{|c|}{ Group B (Diabetes ) } \\
\hline & A1 & A2 & A3 & A4 & B1 & B2 & B3 & B4 \\
\hline Mean & $1.42 \mathrm{a}$ & $1.11^{\mathrm{a}}, \mathrm{e}$ & $1.33 b$ & 1.17b,f & $1.39 c$ & $0.57 c, e, g$ & $1.36 \mathrm{~d}$ & 1.05d,f,g \\
\hline sd & 0.2 & 0.3 & 0.3 & 0.2 & 0.2 & 0.4 & 0.4 & 0.3 \\
\hline Median & 1.37 & 0.8 & 1.28 & 1.10 & 1.33 & 0.35 & 1.30 & 0.8 \\
\hline
\end{tabular}

No ESW x ESW

Mann-Whitney test $\left(\mathrm{Z}\right.$ crit = 2.12): $\mathbf{a A} 1>\mathrm{A} 2\left(\mathrm{Z}\right.$ cal =2.68*); $\mathbf{b} \mathrm{A} 3>\mathrm{A} 4\left(\mathrm{Z}\right.$ cal $\left.=2.42^{*}\right)$; $\mathbf{c}$ B1 $>$ B2 $(\mathrm{Z}$ cal =3.38*); d B3>B4 $(\mathrm{Z}$ cal=3.75*)

Non diabetes $\mathrm{x}$ diabetes

Mann-Whitney test $(\mathrm{Z}$ crit = 2.12): A1 = B1 ( $\mathrm{Z} \mathrm{cal} \mathrm{=1.48);} \mathrm{eA2>B2} \mathrm{(} \mathrm{Z} \mathrm{cal=} \mathrm{2.83*);} \mathrm{A3=B3} \mathrm{(Zcal=1.75);} \mathrm{f} \mathrm{A4} \mathrm{>B4} \mathrm{(Z} \mathrm{calc=} \mathrm{2.97*)}$

One x Two ESW

$\mathrm{A} 2=\mathrm{A} 4(\mathrm{Z}$ cal=1.14); g B2 $<\mathrm{B} 4(\mathrm{Z} \mathrm{cal}=2.84 *)$ 


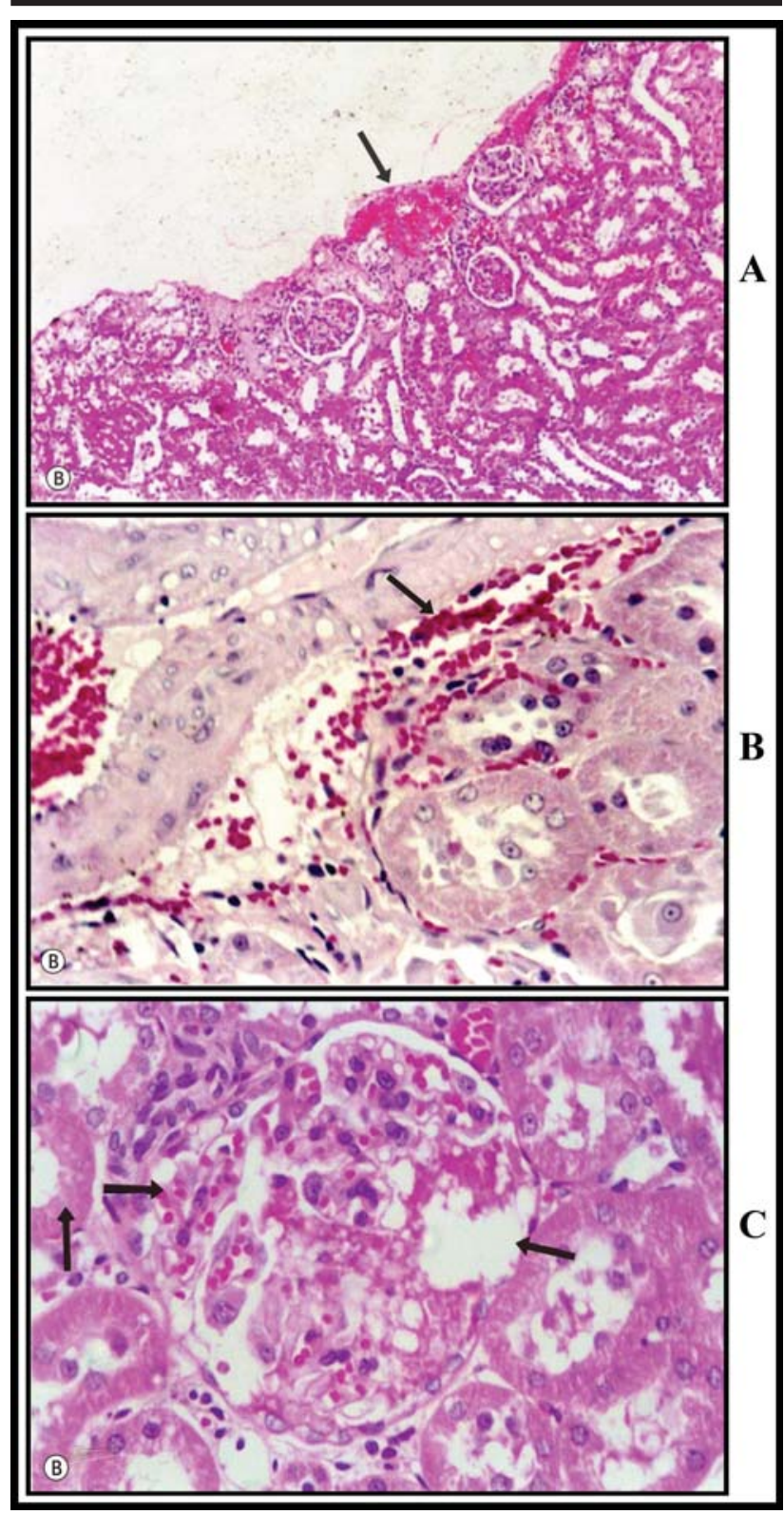

FIGURE 1 - Photomicrography of hemorrhagic focus (HF). A-subcapsular area and mild hemorrhage (arrow) (H\&E-200X). Binterstitial area and mild hemorrhage (arrow) (H\&E -400X). C- glomerular area and mild hemorrhage (arrows) on renal cortex. (H\&E -400X)

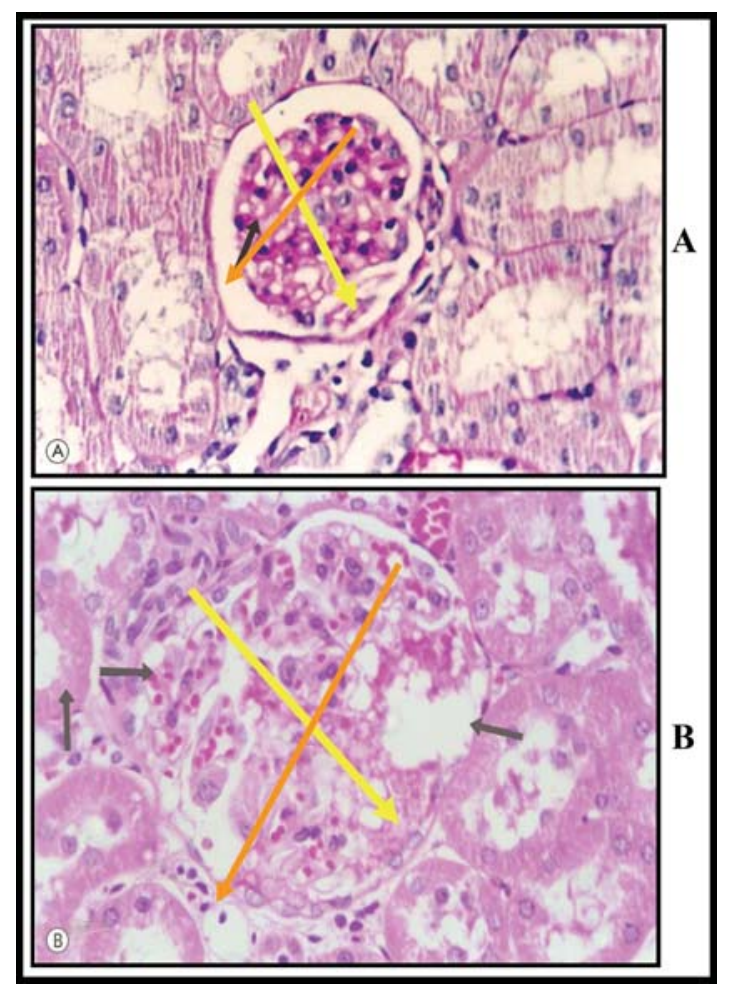

FIGURE 2 - Photomicrography of glomerular area of normal rat (A) and a mild hemorrhage (black arrow) of glomerular area of a diabetic rat and the diameters $(\mu \mathrm{m})$ of Bowman capsule (yellow arrow) and glomerulus (orange arrow). (H\&E -200X)

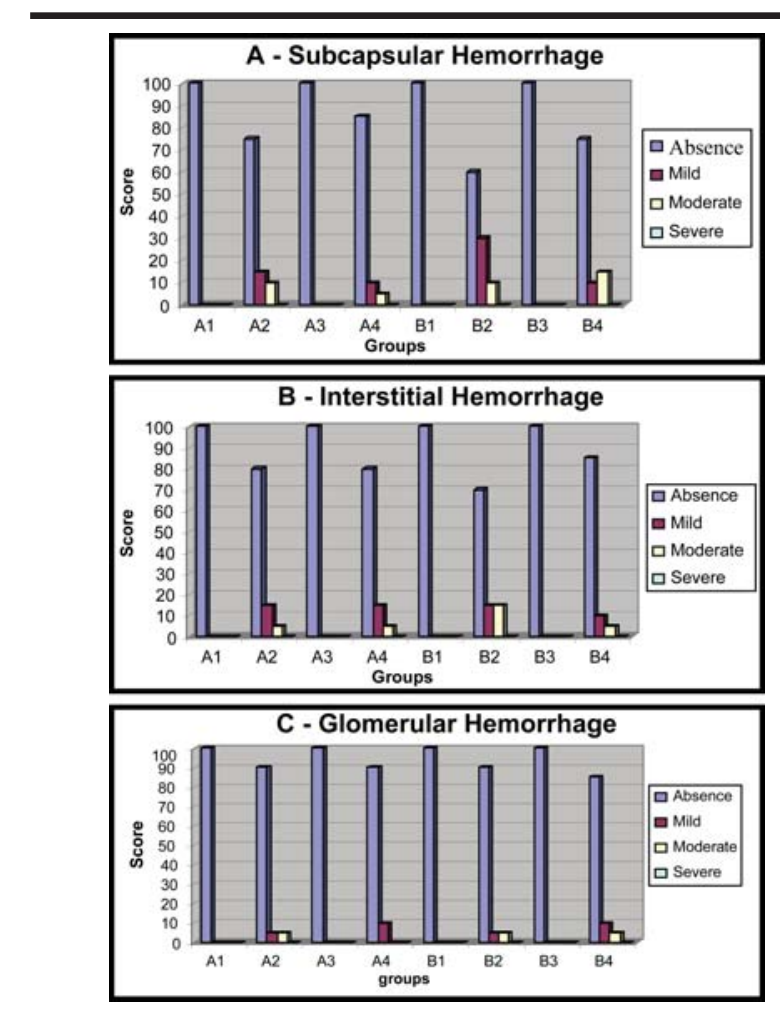

FIGURE 3 -Plotted occurrence (frequency in percentage) of hemorrhagic focus on subcapsular (A), interstitial (B) and glomerular (C) areas on renal cortex of normal and diabetic rats with one session ESW (A4 / B4) or repeated ESW (A2 / B4) 


\section{Discussion}

Experimental works using rabbits ${ }^{10}$, dogs ${ }^{11,12}$ pigs $^{3,13-}$ ${ }^{15}$ and rats ${ }^{2,5,15,16}$ confirm the transient and focal ESW renal injury. Some factors can produce contradictory results including the sample size, different equipments with different energy principles, number of impulses and focus $s^{2} e^{2}$. In our experimental model, the area affected by the shock wave, with the lithotriptor employed in small animal kidney such as rat would have a proportionally larger area (100\%) of the renal parenchyma affected by the shock wave in comparison to humans (10\%), but a proportional dose of energy for lithotripsy (2,000 EWS) as used in humans was used by the authors. Diabetes is a disease that promotes morphological and biochemical changes ${ }^{6,7}$ that worsen the conditions of renal parenchyma and is an etiologic impairment in the follow-up of urolithiasis treatment ${ }^{17}$. The present experimental model of diabetes induced by alloxan was enough, 30 days after ${ }^{8}$, to promote a diabetic nephropathy confirmed by the 24 hours microalbuminuria values $^{4}$ (Table 1). Research in lithotripsy started with the effort to characterize acute shock wave damage to the kidney. It is appreciated now that shock wave trauma is primarily a vascular lesion, that injury is dose dependent, and if the hemorrhage is severe may be associated to a permanent loss of functional renal mass. ${ }^{13,18,19}$. Our results confirm the vascular injury due to ESW. As it was expected, it was not identified any hemorrhage focus (HF) in all normal or diabetic animals without ESW (A1, A3 and B1, $\mathrm{B} 3)$. In the normal rats the HF frequency was similar with one ESW (A4) in the three areas (subcapsular $=15 \%$; interstiticial $=20 \%$ and glomerular $=10 \%$ ) or repetead ESW (A2) in the same areas ( subcapsular $=25 \%$; interstitial $=20 \%$; glomerular =10\%). A second ESW after fourteen days did not improve the HF frequency. The elapsed time will be enough to promote a complete recovery of the first ESW. Overall, this animal model, based on those parameters of morphological injury showed quite appropriated for the study of the effects of ESW on renal parenchyma. The lack of a consensus concerning the choice of time interval to repeat ESWL is due to enormous variability of particular conditions found in the use of ESWL in humans ${ }^{4,7,20}$ and the limitations of the animals model ${ }^{19-21}$. Our animal model suggests that the mild vascular injury on the renal parenchyma can be recovered in fourteen days, as is showed by the current reports in the biomedical literature ${ }^{16,18,22}$. On the other hand, on diabetic rats the occurence of HF with repetead ESW (A2) was more frequent in the three areas (subcapsular $=40 \%$; interstitial $=30 \%$ and glomerular $=10 \%$ ) than with a single ESW (A4) in the same three areas (subcapsular $=25 \%$; interstitial $=15 \%$ and glomerular $=15 \%$ ). Diabetes is a disease that promotes morphological and biochemical changes that worsen the conditions of renal parenchyma and it is an etiologic impairment in the follow-up of urolithiasis treatment ${ }^{7}$. Our experimental results suggested that the diabetes can improve the risk of renal injury in the treatment with repetead ESW. The transient functional damage after ESW would be a result of morphological injury to the nephrons ${ }^{12,13,21}$. Plasmatic and urinary markers such as $\mathrm{N}$ acetyl-beta-glucosaminidase (NAG), beta-galactosidase, gamma-glutamyl-transferase and high molecular weight proteins such as macroglobulins and calbidin d28K assessed renal trauma resulting from shock waves because they are proteins that, under normal conditions, are not filtered by the glomerulus ${ }^{2,4}$. In our work the ESW caused an injury to the nephrons expressed by the measure of the ratio between the capsule of Bowman diameter and the glomerulus diameter(Table 2). In normal rats occurred a thin peripheral space of $2,0-3,0 \mu m$ (Figure 2A) that diminished or disappeared in some groups like in diabetic rats with two ESW (Figure 2B). The enlargement of glomerulus was not only due to hemorrhage focus but mainly by the liquid sequestration causing the edema. In the normal rats the edema was similar to one or two ESW and, similar to the HF, can recover in fourteen days. However, in diabetic animals the edema was more intense and worst after the second ESW. These findings suggest once more, that diabetes was a risk factor for reapplication of ESW. Considering the effects of ESW on the frequency of hemorrhage focus and glomerulus impairment suggsted by this work, and the well known fact that the damage is dose-dependent, staged ESW should be advisable in a clinical setting of diabetic patient.

\section{Conclusion}

A single ESW (2,000 SW) or a repeated ESW (4,000 SW) caused a mild and similar damage on renal cortex of normal rats. In diabetic rats the repetead ESW $(4,000$ SW) may result in an accumulated damage, especially with focus of hemorrhage in subcapsular and interstitial tissue and glomerulus edema.

\section{References}

1. Moe WO. Kidney stones: pathophysiology and medical management. Lancet. 2006; 367(9507):333-44.

2. Fortes MAQR, Andriolo A, Ortiz V, Srougi M. Effect of shock wave reapplication on urinary n-acetyl-betaglucosaminidase in canine kidney. Int Braz J Urol. 2004;30 (2):148-54.

3. Willis LR, Evan AP, Connors BA, Shao Y, Blomgren PM, Pratt JH, Fineberg NS, Lingeman JE. Shockwave lithotripsy: dose-related effects on renal structure, hemodynamics, and tubular function. J Endourol. 2005;19(1):90-101.

4. Cancho MJG, Rodríguez RRD, Chamorro MV, Román CA, Cabrera JAC, Panõ PL. Estudio comparativo del daño renal producido tras la litotricia según la localización litiásica Actas Urol Esp. 2005;29(4):373-7. 
5. Kira VM, Kaufmann OG, Ortiz V, Srougi M. Morphological alterations following of retreatment eletrohidraulic shock waves in rat kidney. J Endourol. 2000;14 (suppl 1):A6 (BS2-2).

6. Mbarki M, Jabrane J, Oussama A, Daudon M. Study of crystalluria in diabetic patients. Prog Urol. 2005;15(3):420-5.

7. Krambeck AE, Gettman MT, Rohlinger AL, Lohse CM, Patterson DE, Segura JW. Diabetes mellitus and hypertension associated with shock wave lithotripsy of renal and proximal ureteral stones at 19 years of followup. J Urol. 2006;175(5):1742-7.

8. Seidel AC, Fagundes DJ, Bazotte RB, Novo NF, Juliano Y, Meister H. Effect of lung resection and sham surgery on the frequency of infection in alloxan-diabetic rats. Braz J Med Biol Res. 2003;36(3):287-90.

9. Frang D, Hamvas A, Kálmán J, Pánovics J, Hegedüs M, Szücs M, Hoznek A. Experience with the Direx Tripter X-1 shock-wave lithotripter. Int Urol Nephrol. 2007; 24(5): 481-90.

10. Loske AM, Prieto FE, Gutierrez J, Zendejas H, Saita A, Velez Gomez E. Evaluation of a bifocal reflector on a clinical lithotripter J Endourol. 2004;18(1):7-15.

11. Block G, Adams LG, Widmer WR, Lingeman JE. Use of extracorporeal shock wave lithotripsy for treatment of nephrolithiasis and ureterolithiasis in five dogs. J Am Vet Med Assoc.1996;208(4):531-6.

12.Koga H, Matsuoka K, Noda S, Yamashita T. Cumulative renal damage in dogs by repeated treatment with extracorporeal shock waves. Int J Urol.1996;3(2):134-40.

13. Sheir KZ. Lee D. Humphrey PA, Morrissey K, Sundaram CP, Clayman RV. Evaluation of synchronous twin pulse technique for shock wave lithotripsy: in vivo tissue effects. Urology. 2003;62(5):964-7.

14. Paterson RF, Lingeman JE, Evan AP, Connors BA, Williams JC, McAteer JA. Percutaneous stone implantation in the pig kidney: a new animal model for lithotripsy research. J Endourol. 2002;6(8):543-7.

15. Paterson RF, Lifshitz DA, Lingeman JE, Evan AP, Connors BA, Fineberg NS, Williams JC, McAteer JA. Stone fragmentation during shock wave lithotripsy is improved by slowing the shock wave rate: studies with a new animal model. J Urol. 2002; 168(5):2211-5.

16. Nardi AC, Ferreira U, Claro JA, Stopiglia GM, Netto NR. Effects of high-energy shock wave on organs adjacent to the kidney in the growing rat. Int Braz $\mathrm{J}$ Urol. 2004; 30(2):142-7.

17.Pak CY, Sakhaee K, Moe O, Preminger GM, Poindexter JR, Peterson RD, Pietrow P, Ekeruo W. Biochemical profile of stone-forming patients with diabetes mellitus. Urology. 2003;61(3):523-7.

18. Strohmaier WL, Billes IC, Abelius A, Lahme S, Bichler KH.Selenium reduces high energy shock wave-induced renal injury in rats. Urol Res. 2002;30(1):31-4.

19. Bailey MR, Pishchalnikov YA, Sapozhnikov OA, Cleveland RO, McAteer JA, Miller NA, Pishchalnikova IV, Connors BA, Crum LA, Evan AP. Cavitation detection during shock-wave lithotripsy. Ultrasound Med Biol. 2005;31(9):1245-56.

20. McAteer JA, Bailey MR, Williams Jr JC, Cleveland RO, Evan AP. Strategies for improved shock wave lithotripsy. Minerva Urol Nefrol. 2005;57(4):271-87.

21. Shao Y, Connors BA, Evan AP, Willis LR, Lifshitz DA, Lingeman JE. Morphological changes induced in the pig kidney by extracorporeal shock wave lithotripsy: nephron injury. Anat Rec A Discov Mol Cell Evol Biol. 2003;275(1):979-89.

22. Al-Ansari A, As-Sadiq K, Al-Said S, Younis N, Jaleel OA, Shokeir AA. Prognostic factors of success of extracorporeal shock wave lithotripsy (ESWL) in the treatment of renal stones. Int Urol Nephrol. 2006;38(1):63-7.

\section{Correspondence:}

Djalma José Fagundes

Rua Camé, 244/33

03121-020 São Paulo - SP Brazil

Phone: (55 11)6604-44 08

djfagundes.dcir@epm.br
Conflict of interest: none Financial source: none

Received: March 12, 2007

Review: May 15, 2007

Accepted: June 14, 2007

\section{How to cite this article}

Kira VM, Fagundes DJ, Bandeira COP, Fagundes ATN, Ortiz V. The repeated extracorporeal shock waves and the renal parenchyma injury on normal and diabetic rats. Acta Cir Bras. [serial on the Internet] 2007 July-Aug;22(4). Available from URL: http://www.scielo.br/acb 